\title{
The identity of Cassinia uncata A.Cunn. (Asteraceae: Gnaphalieae)
}

\author{
Anthony E. Orchard
}

PO Box 3427, Weston Creek ACT Australia 2611

\begin{abstract}
Cassinia uncata A.Cunn. was described from over-mature incomplete material, and its identity has been a long-standing source of confusion. The name has been misapplied to at least 27 different species of Cassinia and one of Haeckeria by many authors, and far from being the widespread and common species of much Australian literature, C. uncata is shown to be rare and possibly vulnerable, and confined to inland New South Wales and South Australia. A lectotype and an epitype are chosen for C. uncata and a full description and list of existing specimens is provided.
\end{abstract}

\section{Introduction}

In June 1823, on a journey north from Bathurst, Allan Cunningham stood at the summit of Pandoras Pass through the Liverpool Range and looked down on to the Liverpool Plains. Short of food, he had no time to explore this area, but his glowing report led to rapid expansion of settlement and follow-up expeditions by Oxley and others.

On 29 March 1825 Cunningham left Parramatta and again visited the Liverpool Plains district. He crossed Pandoras Pass in April 1825 and descended on to the plain itself, following the course of Coxs Creek north from about the present site of Bundella almost to Boggabri. Somewhere in this traverse of the Liverpool Plains he collected several specimens of a shrubby asteraceous plant, which had finished flowering but still retained a few old heads.

In 1827 Cunningham returned to the Liverpool Plains district for a further expedition north to the Brisbane River, during which he was to discover the Darling Downs (McMinn 1970). In early May 1827 he crossed the eastern end of the Liverpool Plains, following the Mooki River, near the present town of Breeza. It is possible that he again saw and perhaps collected the same plant.

In 1834 he wrote to A.P. de Candolle describing this plant, and providing a duplicate of one of his specimens. De Candolle included this description in the Prodromus 
(Candolle 1838), attributing it to Cunningham: "in dumetis siccis ad partem occid. planitierum Liverpool maio fere deflor. legit A. Cunningham. Species quoad flores incompletos dubia, sed ex foliis distinctissima, nunc in hort. kew culta (v.s. sp. etc.)". Cunningham and de Candolle were wise to describe this plant as 'dubia', because the poor description, composed mainly of vegetative characters, and the fragmentary type collections subsequently led to complete confusion as to the identity of C. uncata.

Bentham (1867) reduced Cunningham's species to a variety of C. aculeata (C. aculeata var. uncata (A.Cunn.) Benth.), citing 'Liverpool plains, A.Cunningham; Clarence river, Beckler; also in Leichhardt's collection". This action by Bentham, along with his reduction of $C$. adunca to synonymy under $C$. aculeata triggered doubt on the application of the name $C$. uncata in the minds of all subsequent authors, because these three taxa represent three different sections of the genus (see below). For the next 140 years Cassinia was viewed by many as a 'difficult' genus, and some even suggested that it might be congeneric with Ozothamnus. This last idea was challenged by Orchard (2004a, 2005). The white-headed shrubby species of the drier and semiarid regions of SE Australia were considered particularly difficult and variable, and while some $(C$. longifolia, $C$. aculeata, $C$. laevis, $C$. dentata) were recognised fairly readily, the tendency was to treat all plants with white heads and more or less hooked leaf tips as ' $\mathrm{C}$. uncata'.

Orchard (2004a) showed that Cassinia was far more speciose than had been recognised previously, and provided a framework of infrageneric taxa to accommodate the variation within the genus. The two subgenera recognised were distinguished on inflorescence characters, while the sections within subg. Cassinia (the larger of the two) were distinguished principally on achene characters. The two sections within subg. Achromolaena were separated on inflorescence shape and structure.

With this framework in place it was possible to begin understanding the complicated patterns of misapplication of the name C. uncata A.Cunn. Putative type material was found in MEL, K (2 sheets) and G (seen only on microfiche). Immediately a number of problems became apparent. All of Cunningham's collections were made late in summer/autumn, when flowering and fruiting was almost over. The few remaining flower heads are disintegrating, and there are few fruits and no flowers available. However, the inflorescence shape is more or less conical, with mainly alternate capitula, which places the species in subg. Achromolaena sect. Achromolaena. Cunningham in de Candolle (1838) had referred to the lack of flowers, but commented on the distinctive leaves. This is certainly so: the tips of the linear leaves are abruptly reflexed at $90^{\circ}$, and slightly expanded at the bend, producing two bullate bulges. The deltoid apiculum formed by extension of the midrib, and found in many Cassinia species, is present, but well beyond the point of flexure. When this leaf shape was compared with most other specimens that had been referred to C. uncata, it was found that these other specimens mainly had gradually reflexed leaf tips, not the slightly flattened and abrupt bend of true C. uncata. In addition, many of the plants previously determined or described as 'C. uncata' had flat-topped inflorescences composed of compound dichasia, diagnostic of subg. Cassinia. In fact only a handful of collections made since Cunningham's original discovery (from near Coolabah, Gilgunnia, Euabalong West and Condobolin in New South Wales and from Danngali Conservation Park in South Australia) could be confidently matched to his type specimens.

A second problem was that the Cunningham specimen in G, de Candolle's herbarium, is numbered 67, while others in MEL and K are unnumbered or numbered 95, suggesting 
that Cunningham may have made more than one gathering. Fortunately, all putative syntypes are of the same species, with its distinctive leaf tips.

In February 2004 I made a number of flowering collections from the Breeza State Forest on the south-eastern margins of the Liverpool Plains, and these closely matched Cunningham's original collections of $C$. uncata. They were growing in association with plants of Cassinia laevis, and closely resembled them in many respects, but differed in having slightly more yellowish inflorescences, and were flowering a few weeks earlier. The leaf tips of C. laevis are almost straight, or if recurved only gently so, quite different to those of C. uncata. When fresh there is also a subtle difference between the two species in the aromatic resinous smell of the leaves. It is perhaps noteworthy that Cunningham also collected C. laevis (A.Cunningham 58, 1825, Liverpool Plains (MEL $221269 \& 1583046)$ ) near this spot in 1825 and obviously noted that it was different to his $C$. uncata. Subsequently, additional collections of $C$. uncata were made by me west of Nyngan, near Pangee and between Nymagee and Gilgunnia, all in New South Wales. These collections have made it possible to provide an expanded description of C. uncata, and to designate an epitype (with duplicates) to provide improved reference material for this rare species.

As mentioned earlier, the name C. uncata has been persistently and widely misapplied to a number of other species. Only some of the more important of these are discussed below. This enumeration is not intended to be critical in any way of the authors involved: the confusion introduced by Bentham and the fragmentary type material made it inevitable that the name would be misapplied until a full revision of the genus was undertaken. The usages of subsequent authors reflected contemporary views, but unfortunately also disguised the fact that Cassinia was far more speciose than previously suspected. Once the identity of $C$. uncata is settled, the rest of the genus becomes far more easily understood. The reputation of Cassinia for being 'difficult' stems almost entirely from the confusion surrounding C. uncata and the medium-sized white-headed taxa of the semiarid of New South Wales, Victoria and South Australia. The history below is intended only to emphasise the scale of confusion over the past 140 years, and to provide an indication where possible of the taxa involved.

Bentham (1867) reduced C. uncata to a variety of C. aculeata, a placement that cannot stand. Cassinia aculeata is the type species of the genus and of subg. Cassinia and sect. Cassinia, while C. uncata belongs in Cassinia subg. Achromolaena sect. Achromolaena. Bentham included in his C. aculeata var. uncata collections by Beckler from the Clarence River, and others by Leichhardt. The Beckler collections have not been located but two specimens of depauperate C. cunninghamii in the Mueller herbarium (MEL 1582832 \& 221360) may be the ones referred to, while the Leichhardt collections were C. lepschii (sect. Costatae). As a footnote to C. aculeata (incl. var. uncata), Bentham referred to specimens collected by Mueller at Macalister River. These are Cassinia nivalis. The specimens "from other parts of Victoria" with "involucral bracts more or less distinctly superposed in 4 or 5 rows" are C. complanata and C. diminuta.

Wakefield (1951) reinstated C. uncata as a species distinct from C. aculeata, believing that it extended from Wallangarra in Queensland throughout eastern New South Wales (including the alps), and scattered across Victoria especially in Gippsland. Wakefield believed that $C$. complanata was closely related, but probably distinct. His concept of C. uncata thus included at least C. lepschii, C. copensis, C. ochracea, C. nivalis and probably C. wyberbensis and C. heleniae all from sect. Costatae, C. maritima, C. monticola, 
C. hewsoniae and C. theresae from sect. Complanatae, and perhaps some forms of C. aculeata (sect. Cassinia) and C. longifolia (sect. Longifoliae).

Willis (1967) reduced C. complanata to a synonym of C. uncata, a position that he maintained in the Handbook to Plants in Victoria (Willis 1973). In the latter publication he gave the distribution of C. uncata in Victoria as "Gippsland valleys, Warby Range, Goulburn R. to Bendigo district, Kerang, Little and Big Deserts", thus including plants now known as C. longifolia (Gippsland valleys) from ser. Longifoliae, possibly C. aculeata and an undescribed related species (Gippsland - sect. Cassinia), C. scabrida and possibly C. ozothamnoides (Warby Range - sect. Venustae), C. diminuta (Goulburn R. to Bendigo district and Kerang) and C. complanata (Little and Big Deserts) — both from sect. Complanatae, and probably a still-undescribed species from Little Desert (sect. Achromolaena). As Willis (1973) also included NSW and the ACT in the distribution of C. uncata, by implication he also included some of the other species mentioned above for Wakefield (1951).

Burbidge and Gray (1970) accepted C. uncata (including C. complanata) with a similar circumscription to that of Willis (1973), a species that they considered extended from Queensland to South Australia. However, they stated that in the ACT region it was most common in the Kosciuszko region and the Victorian Alps, and their concept thus mainly embraced C. monticola (sect. Complanatae) and C. ochracea (sect. Costatae). It may also have included C. hewsoniae (sect. Complanatae) which just reaches the ACT.

Beadle, Evans and Carolin (1972) included C. uncata in their catalogue of the plants of the Sydney region, but it is not clear just what they included in their broadly circumscribed taxon. Candidates are the narrow-leaved form of C. longifolia (ser. Longifoliae) and C. accipitrum (sect.Leptocephalae ser. Compactae). Beadle (1980) used a virtually identical description of C. uncata in his treatment of a broadly defined C. uncata in northeastern New South Wales. In this case, the taxa encompassed included C. cunninghamii, C. macrocephala, C. compacta, C. telfordii and C. straminea (all sect. Leptocephalae) as well as C. lepschii, C. copensis, C. ochracea and probably C. wyberbensis and C. heleniae from sect. Costatae.

Cunningham et al. (1981) probably included elements of true C. uncata in their concept of C. uncata, but their description included characters such as "very sticky shrub" and "flower heads with 4-8 flowers" which suggested a mixed concept, including C. hewsoniae and (although it does not occur in western N.S.W.) C. complanata (both sect. Complanatae).

Eichler (1965) unfortunately confused C. punctulata with C. complanata, adopting the first name for the South Australian/Victorian species, and hinting that both should be considered synonymous with C. uncata. Cassinia punctulata was later shown to be a Haeckeria species by Orchard (2004b). However Jacobs and Pickard (1981) took up Eichler's suggestion, and incorrectly treated C. aculeata var. uncata, C. complanata and C. punctulata as synonyms of C. uncata.

Stanley (1986) recorded C. uncata from south-eastern Queensland, misapplying the name to species now known as $C$. wyberbensis, C. copensis and C. lepschii (all sect. Costatae).

Cooke (1986) recorded C. uncata for South Australia, noting that it was variable. In this work the name $C$. uncata is misapplied to $C$. complanata, $C$. adunca and 
C. tegulata. Ironically, although true C. uncata does occur in South Australia, in Danngali Conservation Park north of the River Murray, Cooke was probably unaware of it from that locality, as all specimens were on loan to the present author at the time, under a different name. Cooke confirmed that Haeckeria punctulata was distinct from Cassinia.

Everett (1992) also adopted a very broad circumscription of C. uncata, probably including true $C$. uncata along with many taxa from sect. Costatae (especially C. copensis, C. lepschii, C. ochracea), sect. Leptocephalae (especially C. accipitrum) and sect. Complanatae (especially C. theresae, C. maritima and probably C. hewsoniae) in particular, but also including a still-undescribed species from subg. Achromolaena.

Puttock (1999) incorrectly recorded C. uncata from Victoria, noting that it apparently had several variants. In this work, the name C. uncata is misapplied to C. complanata, C. diminuta, C. maritima and C. monticola (all sect. Complanatae), and to C. ochracea and C. nivalis (sect. Costatae). In this work Puttock also placed in synonymy "Cassinia arcuata var. uncata", an erroneous reference to Cassinia aculeata var. uncata.

In summary, the name Cassinia uncata has been misapplied, in whole or in part, at one time or another, to all of the following species (see above for details):

Haeckeria F.Muell.:

Haeckeria punctulata (F.Muell.) J.H.Willis

Cassinia R.Br.:

Cassinia sect. Complanatae Orchard: C. $\times$ adunca F.Muell. ex Sonder (C. complanata $\times$ C. tegulata), C. complanata J.M.Black, C. diminuta Orchard, C. hewsoniae Orchard, C. maritima Orchard, C. monticola Orchard, C. tegulata Orchard, C. theresae Orchard.

Cassinia sect. Venustae Orchard: C. ozothamnoides (F.Muell.) Orchard, C. scabrida Orchard.

Cassinia sect. Leptocephalae Orchard: C. accipitrum Orchard, C. compacta F.Muell., C. cunninghamii DC., C. macrocephala Orchard, C. straminea (Benth.) Orchard, C. telfordii Orchard.

Cassinia R.Br. sect. Cassinia: C. aculeata R.Br., C. longifolia R.Br. and a currently undescribed species from southern Victoria.

Cassinia sect. Costatae Orchard: C. copensis Orchard, C. heleniae Orchard, C. lepschii Orchard, C. nivalis Orchard, C. ochracea Orchard, C. wyberbensis Orchard.

Cassinia sect. Achromolaena Orchard: Two currently undescribed species, one from Victoria and one from New South Wales.

\section{Typification and description}

Cassinia uncata A.Cunn. in DC., Prodr. 6: 156 (1838)

Type citation: "In dumetis siccis ad partem occid. Planitierum Liverpool maio fere deflor. legit cl. A.Cunningham."

Lectotype (designated here): A. Cunningham 95, May 1825, bushy tracts on the 
Western side of Liverpool Plains, N. S. Wales, K!. Isolectotypes: A. Cunningham 95, s. dat., Shrub 5 f. high. W. skirts of Liv. Plains, K!; A. Cunningham 95, s. dat., NSW (MEL 221362!). Residual syntype: A. Cunningham 67, Liverpool Plains, G (seen microfiche). Epitype (designated here): New South Wales, North Western Slopes, $6 \mathrm{~km}$ along Spring Ridge road, c. 8 km due W of Breeza, A.E. Orchard $7196 \&$ T.A. Orchard, 12 Feb 2004, NSW! Duplicates of epitype in AD!, CANB!

Erect shrubs 1-2 m tall, to $1 \mathrm{~m}$ diam., with faint resinous smell; older branches with light brown bark becoming slightly fissured longitudinally; young twigs olive brown with a dense indumentum of white woolly hairs with occasional emergent spreading multiseriate hairs $0.1-0.2 \mathrm{~mm}$ long and occasionally gland-tipped, rarely absent, and sparse subsessile globular hairs. Leaves alternate, spreading, not decurrent, sessile, narrowly linear to terete, 6-12 (-15) mm long, 0.5-1.0 mm wide; upper surface midgreen, dull, rugose, glabrous and sometimes somewhat viscid above; lower surface obscured by margins revolute to midrib, covered (including midrib) with (at least in proximal part) dense woolly hairs and underlying subsessile globular glandular hairs; midrib sunken above, prominent below; tip truncate, slightly flared (bullate) and abruptly reflexed, with a deltoid apiculum. Inflorescence a subconical dense head of 25-100 capitula arranged \pm alternately along the branched inflorescence axes, the uppermost capitula sometimes subdichasial. Capitula $3.0-3.5 \mathrm{~mm}$ long, tapering to base, appearing off-white to cream from a distance, with phyllaries white tipped and green below. Receptacle small, flat to slightly elongate. Phyllaries 18-20, all papery, spirally arranged in 4-6 whorls, or sometimes somewhat vertically ranked. Outermost phyllaries tiny, \pm orbicular, green hyaline, $0.5-0.6 \mathrm{~mm}$ long, glabrous. Inner phyllaries narrowly oblong to narrowly ovate, $2.3-3.0 \mathrm{~mm}$ long, $0.7-1.1 \mathrm{~mm}$ wide, blunt; stereome green, becoming golden brown, glabrous apart from a few subsessile globular hairs; lamina wing narrow (c. $0.1-0.2 \mathrm{~mm}$ ), hyaline; lamina tip opaque creamy white, with a green hyaline section below. Paleae $2.4 \mathrm{~mm}$ long, $0.6 \mathrm{~mm}$ wide, similar to inner phyllaries but more lanceolate, tapering to an acute slightly lacerate tip, with stereome less developed. Pappus of 17-18 flattened bristles, fused at extreme base, barbellate on margins, slightly swollen at tip; cells at tip clavate, obtuse. Corolla greenish cream; tube (1.4-) 1.5-2.0 $\mathrm{mm}$ long, tapering to base, $0.4-0.5 \mathrm{~mm}$ diam. at throat, $0.1 \mathrm{~mm}$ diam. at base, swollen around stylopodium; lobes deltoid, spreading, glabrous, c. $0.4 \mathrm{~mm}$ long. long and about as wide as the thecae; tails short; filament collars $0.28-0.30 \mathrm{~mm}$ long, golden yellow. Style c. $2 \mathrm{~mm}$ long plus reflexed arms c. $1 \mathrm{~mm}$ long, with a terminal stigmatic brush. Stylopodium small, almost smooth, depressed globular. Ovary shortly cylindrical, $0.5-0.6 \mathrm{~mm}$ long, $0.25 \mathrm{~mm}$ diam., golden brown, with sparse to moderately dense biseriate gland-tipped hairs c. $0.1 \mathrm{~mm}$ long; carpopodium small, white. Fruit not seen fully mature, olive brown to blackish, spindle shaped, 0.6-1.0 mm long, with sparse semiappressed biseriate gland-tipped hairs; pappus shed as a ring of bristles (Fig. $1 \mathrm{a}-\mathrm{v}$ ).

Distribution: confined to the North Western Slopes, Central Western Slopes, North Western Plains and South Western Plains districts of New South Wales, with an outlier in the northern Murray district of South Australia. Previous records from Victoria, Queensland and districts of New South Wales and South Australia other than those listed above, are erroneous (Fig. 2).

Ecology: found in dry open woodland dominated by mallee Eucalyptus, Casuarinaceae, Callitris and shrubby Acacia spp., often on sandy or loam soils with flat or undulating topography. Most populations are small and localised, and seed set seems to be poor. 

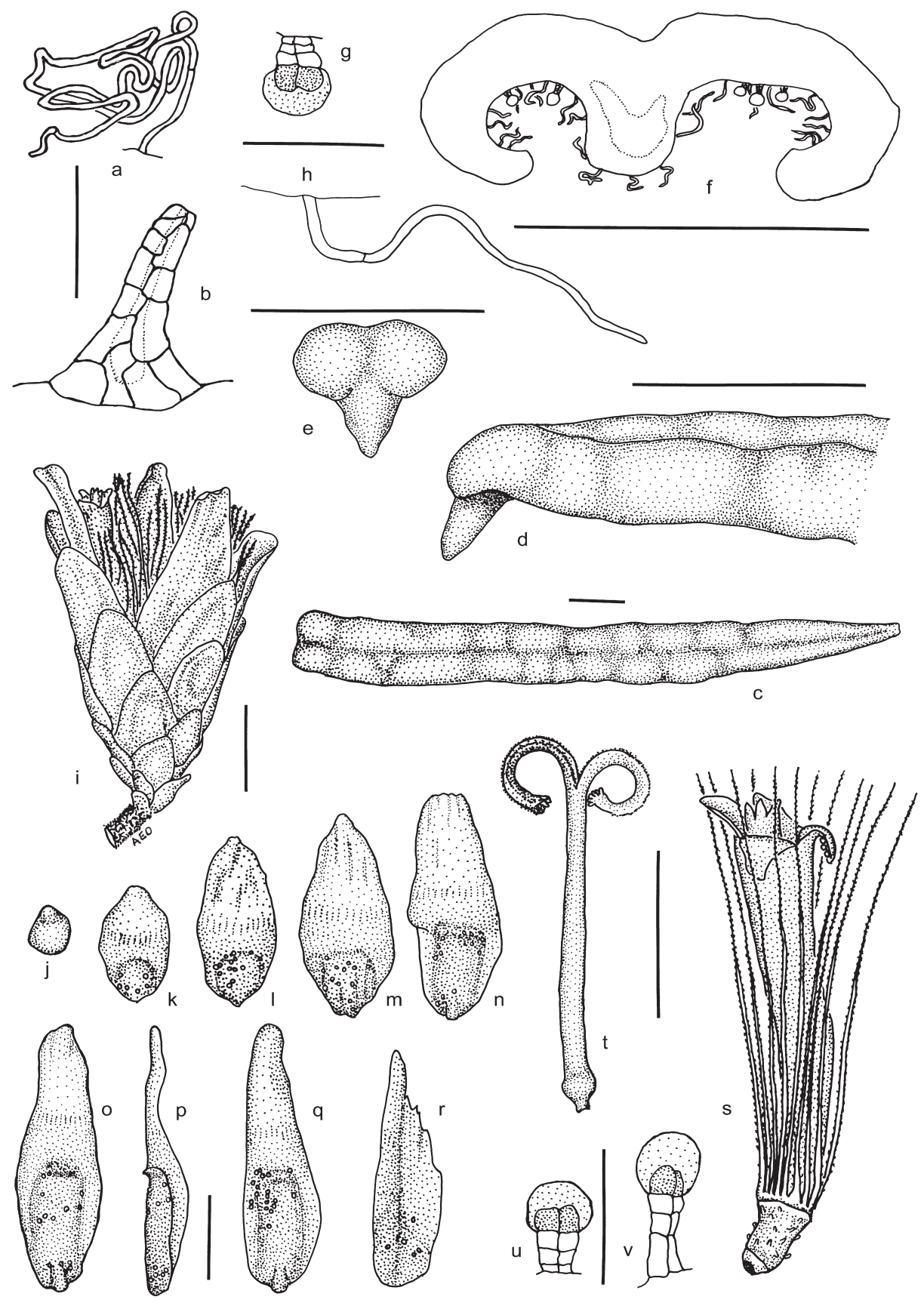

Fig. 1. Cassinia uncata. a, woolly stem hair. b, multiseriate stem hair. c, mature leaf, adaxial surface. d, leaf, lateral view of tip. e, leaf, end-on view of tip. f, leaf semidiagramatic transverse section. g, subsessile globular hair from undersurface of leaf. $h$, woolly hair from undersurface of leaf. $\mathbf{i}$, capitulum. $\mathbf{j}-\mathbf{q}$, involucral bracts in abaxial view, series from outer to inner ( $p$ is a lateral view of o). r, palea. s, floret. t. style. u, v, biseriate gland-tipped hairs from ovary. All drawn from R.N.Peacock s.n., NSW 13922. Scale bars represent $0.1 \mathrm{~mm}$ (a, b, g, h), or $1 \mathrm{~mm}$ (c-f, i-v). 
Flowering occurs from February to March.

Specimens examined: South Australia: Murray: Danggali Conservation Park, Conrick 713, 29 Feb 1982 (AD, HO, MEL); Danggali Conservation Part, S of Birthday Dam, N of Smiths Dam, Cunningham 569 \& Moore, 3 Mar 1993 (AD, CBG, STU); $9.5 \mathrm{~km}$ due S of Canopus HS, Williams 7743, 24 Feb 1976 (AD). New South Wales: North Western Slopes: 6 km along Spring Ridge road, c. $8 \mathrm{~km}$ due W of Breeza, Orchard \& Orchard 7195, 12 Feb 2004 (AD, BRI, CANB, MEL, NSW); loc. cit., Orchard. \&.Orchard 7197, 12 Feb 2004 (AD, BRI, CANB, NSW); loc. cit., Orchard \& Orchard 7199, 12 Feb 2004 (CANB, MEL, NSW). Central Western Slopes: Condobolin, Maiden s.n., 1888 (NSW 13921). North Western Plains: $18 \mathrm{~km}$ from Buddabadah on road to Nymagee, Orchard \& Orchard 7225, 14 Feb 2004 (AD, BRI, CANB, MEL, NE, NSW); Peisley State Forest, 45 $\mathrm{km}$ from Buddabadah on road to Nymagee, c. $1 \mathrm{~km}$ W of Pangee, Orchard \& Orchard 7229, 14 Feb 2004 (AD, CANB, NSW); loc. cit., Orchard \& Orchard 7230, 14 Feb 2004 (AD, CANB, NSW); Coolabah, Peacock s.n., 1900 (NSW 13922). South Western Plains: Gilgunnia, Bauerlen 3190 p.p., Feb 1900 (NSW 445755); Gilgunnia, Bauerlen 3190 p.p., Feb 1904 (AD 118634 \& 118635, BRI, NSW 3190, 13920 \& 437909); $4 \mathrm{~km} \mathrm{~W}$ of Euabalong West along railway line, Cunningham \& Milthorpe 5367, Feb 1978 (NSW); Nymagee-Gilgunnia road, 15 km from Nymagee, Orchard \& Orchard 7231, 14 Feb 2004 (AD, CANB, MEL, NSW); 7 km NE of Gilgunnia on Nymagee road, Orchard \& Orchard 7232, 14 Feb 2004 (AD, BRI, CANB, NSW); 2 km SW of Gilgunnia Rest Area on Kidman Highway, Orchard \& Orchard 7233, 14 Feb 2004 (AD, BRI, CANB, MEL, NSW).

Note: the authorship of this species name is often cited as C. uncata A.Cunn. ex DC. However, as de Candolle clearly stated that the description of the plant was based on

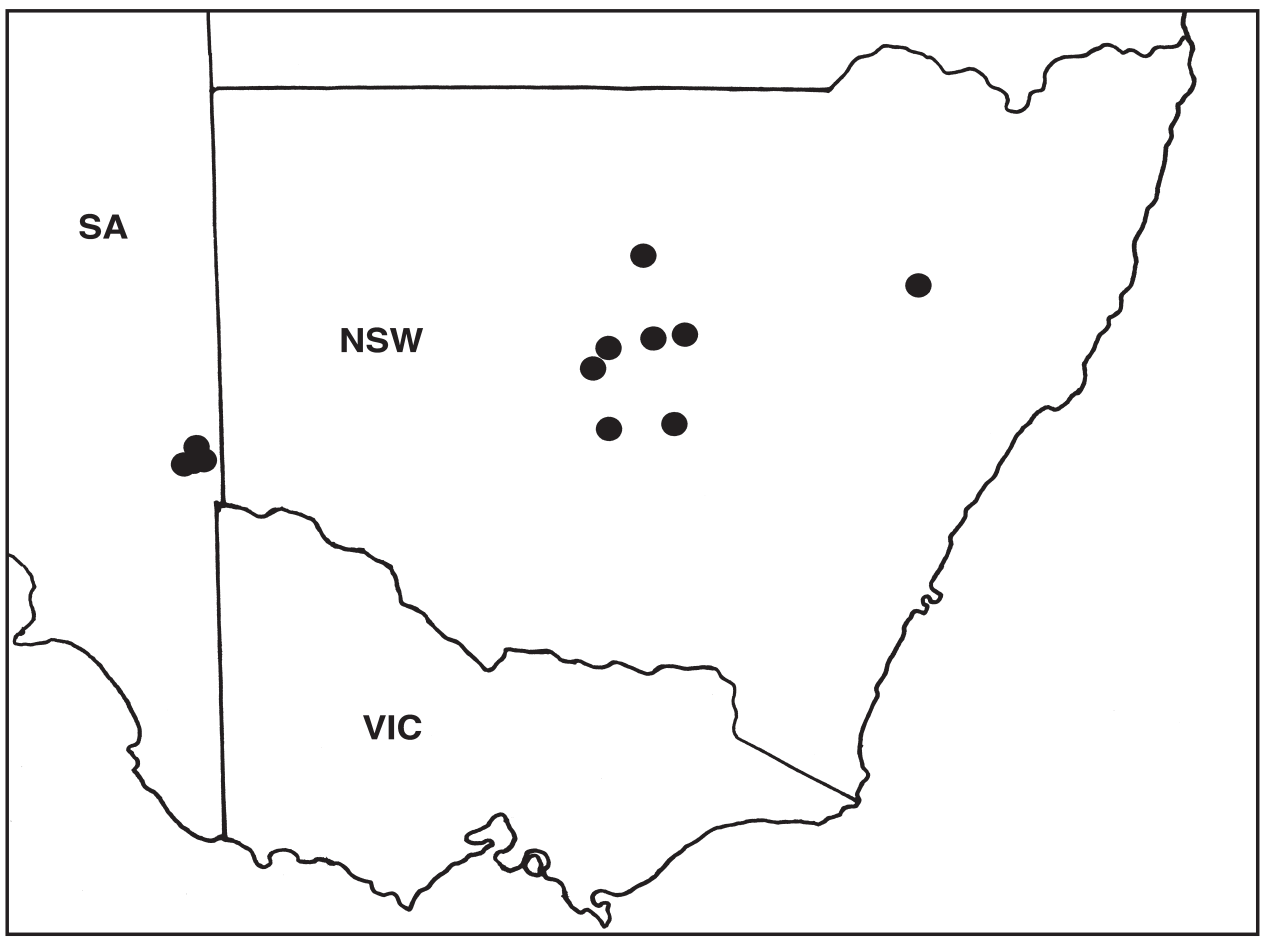

Fig. 2. Distribution of Cassinia uncata in south-eastern Australia. 
information in a letter from Allan Cunningham, it seems more appropriate to attribute it as $C$ uncata A.Cunn. in DC. This being the case, it seems appropriate to designate a Kew Herbarium specimen as lectotype rather than the one in Geneva, although it could be argued that, if Cunningham is both collector (of all material available in 1838) and describer of the species, all of his specimens are probably of equal weight in choice of lectotype.

Conservation considerations: because the name Cassinia uncata has been misapplied to so many other taxa, the species has until now been considered widespread, common and secure. However, the investigations reported here show that $C$. uncata is in fact a relatively rare species of very limited distribution. Many collections and collection sites are old ones. It has not been collected from the vicinity of Condobolin since 1888, or Coolabah since 1900. A search at Euabalong West in 2004 failed to find the species where it had been reported in 1978, although it may have been overlooked (the confusingly similar C. laevis was present). Virtually all known surviving populations consist of one to very few individuals. For example, the population in Peisley State Forest (Orchard \& Orchard 7229, 7230) consisted of just two plants, those between Gilgunnia and Nymagee (Orchard \& Orchard 7232) of a single plant or (Orchard \& Orchard 7231) of seven plants, and that at Gilgunnia Rest Area (Orchard \& Orchard 7233) of just four plants. Populations in and near Breeza State Forest are slightly larger, and some seedlings were noted. No information on the size of the South Australian populations is available, but as all are within the Danggali Conservation Park they must be assumed reasonably secure. The species probably survives in other populations in central-west New South Wales, but it is likely that it is nowhere common, and it should be treated as vulnerable.

\section{Acknowledgments}

I thank my wife and field companion Theresa for patient and observant hours spent hunting elusive Cassinia species in several States. This paper was based in part on examination of specimens borrowed from or consulted in a number of herbaria $(A D$, BRI, CANB (incl. CBG), HO, K, MEL, NSW). The Directors, staff and curators of these institutions are thanked for their generosity and patience in making this material available (and in some cases for hosting me on visits to their collections). The Director and staff of CANB are thanked also for their support in providing a congenial place to carry out the research. The original research on which this paper is based was supported in part, many years ago, by a research grant from the Australian Biological Resources Study to the Tasmanian Herbarium. I thank Annette Wilson (ABRS) for assistance with scanning of the illustrations.

\section{References}

Beadle NCW (1980) Students flora of north eastern New South Wales, vol. 4. (University of New England: Armidale)

Beadle NCW, Evans OD \& Carolin RC (1972) Flora of the Sydney region. (AH \& AW Reed: Sydney)

Bentham G (1867) Flora Australiensis, vol. 3. (Lovell Reeve \& Co.: London)

Candolle AP de (1838) Prodromus systematis naturalis regni vegetabilis, vol. 6. (Treutel \& Würtz: Paris, Strasbourg \& London) 
Cooke DA (1986) Cassinia. Pp. 1504-1506 in Jessop JP \& Toelken HR (eds) Flora of South Australia, vol. 3. (South Australian Government Printer: Adelaide)

Cunningham GM, Mulham WE, Milthorpe PL \& Leigh JH (1981) Plants of western New South Wales. (NSW Government Printing Office: Sydney)

Eichler H (1965) Supplement to J.M.Black's flora of South Australia. (Government Printer: Adelaide)

Everett J (1992) Cassinia. Pp. 211-216 in Harden GJ (ed) Flora of New South Wales, vol. 3. (New South Wales University Press: Kensington)

Jacobs SWL \& Pickard J (1981) Plants of New South Wales. (National Herbarium of New South Wales: Sydney)

Burbidge NT \& Gray M (1970) Flora of the Australian Capital Territory. (ANU Press: Canberra)

McMinn WG (1970) Allan Cunningham botanist and explorer. (Melbourne University Press: Carlton)

Orchard AE (2004a) A revision of Cassinia (Asteraceae: Gnaphalieae) in Australia. I. Introduction and generic and infrageneric considerations. Australian Systematic Botany 17: 469-481.

Orchard AE (2004b) A reassessment of the genus Haeckeria (Asteraceae: Gnaphaliae), with definition of a new species in Cassinia. Australian Systematic Botany 17: 447-467.

Orchard AE (2005) (1676) Proposal for the conservation of Cassinia R.Br. (1817) nom. cons. (Asteraceae) against an additional name Ozothamnus, or to change its date of publication to Cassinia R.Br. (1813), Taxon 54 (1): 199-201.

Puttock CF (1999) Cassinia. Pp 742-745 in Walsh NG \& Entwisle TG (eds) Flora of Victoria, vol. 4. (Inkata Press: Melbourne)

Stanley TD (1986) Cassinia. Pp 540-541 in Stanley TD \& Ross EM (eds) Flora of south eastern Queensland, vol. 2. (Queensland Herbarium: Brisbane)

Wakefield NA (1951) Some notes on Cassinia with description of a new species. Victorian Naturalist 68: 69-70.

Willis JH (1967) Systematic notes on the indigenous Australian flora. Muelleria 1: 117-163. Willis JH (1973) Handbook to plants in Victoria, vol. 2. (Melbourne University Press: Carlton) 